\title{
Neuronal Activity Differentially Regulates NMDA Receptor Subunit Expression in Cerebellar Granule Cells
}

\author{
Mary Lou Valiano, ${ }^{1}$ Bertrand Lambolez, ${ }^{2}$ Etienne Audinat, ${ }^{2}$ and Jean Rossier ${ }^{2}$ \\ 1 Department of Pharmacology, State University of New York Health Sciences Center, Syracuse, New York 13210 , and \\ zinstitut Alfred Fessard, Centre National de la Recherche Scientifique, 91198 Gif-sur-Yvette, France
}

Reverse-transcription PCR assays were used to measure levels of NMDA receptor (NR) subunit mRNAs encoding splice variants of NR1 (NR1a, - exon 5; NR1b, +exon 5) and the major NR2 subunits (NR2A, NR2B, and NR2C) in dissociated cerebellar granule cell cultures. Cultures chronically exposed to 25 $\mathrm{mm} \mathrm{KCl}$ or $100 \mu \mathrm{M}$ NMDA $15 \mathrm{~mm} \mathrm{KCl}$, which promote survival by stimulating $\mathrm{Ca}^{2+}$ influx through voltage-sensitive $\mathrm{Ca}^{2+}$ channels or NRs, were compared with $5 \mathrm{~mm} \mathrm{KCl}$ culture conditions, which results in limited cell survival attributable to a lower level of NR stimulation by ambient glutamate. In situ granule-cell maturation is associated with downregulation of $\mathrm{NR} 2 \mathrm{~B}$ and increases both of NR2A and NR2C and in the ratio of NR1b/NR1a mRNAs. In culture, $25 \mathrm{~mm} \mathrm{KCl}$ or NMDA rapidly induced NR2A and downregulated NR2B, followed by gradual induction of NR2C. In $5 \mathrm{~mm} \mathrm{KCl}$, a similar, rapid increase in NR2A was observed, but disappearance of NR2B occurred over a longer time course. By $9-12 \mathrm{~d}$ in vitro in $5 \mathrm{mM} \mathrm{KCl}$, the relative proportions of all three NR2 mRNAs in surviving cells were not significantly different from cells cultured in $25 \mathrm{mM} \mathrm{KCl}$. NR1a mRNA predominated at every stage of culture in $25 \mathrm{~mm}$ $\mathrm{KCl}$ or NMDA, however, whereas gradual induction of the mature-form NR1b was observed in $5 \mathrm{~mm} \mathrm{KCl}$. Although using high potassium- or NMDA-containing media enhanced granule cell survival, it did not reproduce the pattern of expression of NR mRNAs observed in situ, whereas this pattern was observed in granule cells surviving in $5 \mathrm{~mm} \mathrm{KCl}$.

Key words: NMDA receptors; RT-PCR; cerebellum; granule cells; development; mRNA; neuronal activity; cell death
Among the ionotropic glutamate receptors, the NMDA receptor (NR) is unique in being both ligand- and voltage-gated (Mayer et al., 1984; Nowak et al., 1984) and in demonstrating a high $\mathrm{Ca}^{2+}$ / $\mathrm{Na}^{+}$permeability ratio (MacDermott et al., 1986). Activation of these receptor channels is required for synapse stabilization and refinement (Constantine-Paton et al., 1990), long-term potentiation (Bliss and Collingridge, 1993), regression of supernumerary climbing-fiber synapses with Purkinje neurons (Rabacchi et al., 1992), and granule-cell migration (Komuro and Rakic, 1993; Rossi and Slater, 1993; Forrest et al., 1994). Regulated expression of distinct heteromeric forms containing an obligatory NR1 subunit, with eight possible variants generated by alternative splicing of three exons, in combination with at least one of four NR2 subunits contributes to the diversity of excitatory synaptic responses (Nakanishi, 1992; Hollmann and Heinemann, 1994; McBain and Mayer, 1994). Moreover, alterations in $\mathrm{Ca}^{2+}$ flux through NRs may provide a feedback system that regulates subunit composition to subserve the different physiological requirements of developing and mature neurons (Scheetz and Constantine-Paton, 1994); however, this hypothesis has not been tested.

Epigenetic programs that define expression patterns of several genes and receptor systems characterize discrete stages of granule-cell migration and differentiation in cerebellar cortex

Received Aug. 28, 1995; revised Oct. 13, 1995; accepted Oct. 17, 1995.

This research was supported by Institut National de la Recherche Médicale Grant 930801 (E.A.), Public Health Service Grant NS-27603 (M.L.V.), and NATO Collaborative Research Grant 950682 . We thank Dr. P. Bochet for critical comments, and we thank F. Bassilana and Jimmy Gorecki for assistance with some of the radioisotope experiments.

Correspondence should be addressed to Dr. Mary Lou Vallano at the above address.

Copyright (19 1996 Society for Neuroscience $0270-6474 / 96 / 160631-09 \$ 05.00 / 0$
(Hatten and Heintz, 1995). $\Lambda$ potentially relevant example is the pattern of neuronal activity at developing mossy fiber-granule cell glutamatergic synapses (Ito, 1984), which has been modeled in dissociated granule-cell cultures. Increased $\mathrm{Ca}^{2+}$ influx caused by long-term exposure of cultures to $25 \mathrm{mM} \mathrm{KCl}$ or NMDA, proposed to mimic mossy-fiber activity in vivo, is positively correlated with enhanced granule-cell survival, differentiation, and NMDA responsiveness (Lasher and Zagon, 1972; Balazs and Hack, 1990; Balazs et al., 1992; Bessho et al., 1994). Alternatively, survival and differentiation are compromised (Gallo et al., 1987) and NRs apparently are downregulated or are not expressed (Cox et al., 1990; Van der Valk et al., 1991) in cells cultured in $5 \mathrm{~mm} \mathrm{KCl,}$ although these cells have not been well characterized because of poor survival after $6 \mathrm{~d}$ in vitro (DIV). In fact, the requirement for at least a low level of NR stimulation by ambient glutamate is supported by the observation that inclusion of NR antagonists in the culture medium suppresses the limited cell survival (Balazs et al., 1988a). Also, a preliminary report suggests that cells cultured in $5 \mathrm{~mm} \mathrm{KCl}$ develop synapses with functional NRs (Irving et al., 1992). Thus, the subpopulation of cells that survives in $5 \mathrm{mM} \mathrm{KCl}$ may express a sufficient number of functional NRs to support further differentiation of the endogenous phenotype. A comparison of granule cells cultured under different conditions should provide a physiologically relevant model to test the hypothesis that different types of neuronal activity in developing neurons can modulate the expression pattern of NRs.

In this study, reverse transcriptase (RT)-PCR assays for distinct NR subunit mRNAs were used to compare the effects of longterm NR activation or depolarization with $25 \mathrm{~mm} \mathrm{KCl}$ with the low level of NR activation obtained with a physiological concentration of $\mathrm{KCl}$ in developing cerebellar granule-cell cultures. 


\section{MATERIALS AND METHODS}

Thermus aquaticus (Taq) polymerase was purchased from Stratagene ( $\mathrm{La}$ Jolla, CA). DNA fragments ( $\varnothing$ X174 DNA/HaelII-digested, 72-1353 bp) Moloney murine leukemia virus (MMLV) reverse-transcriptase, basal Eagle's medium with Earle's salts, and L-glutamine were purchased from Gibco (Gaithersburg, MD). Restriction enzymes BprnI, BfaI, ScaI, and NotI were purchased from New England Biolabs (Beverly, MA). Ribonuclease inhibitor was obtained from Promega (Madison, WI). Hexamer random primers were obtained from Boehringer Mannheim (Indianapolis, IN). The four deoxyribonucleotide triphosphates (dNTPs) were purchased from Pharmacia (Piscataway, NJ). $\left[\alpha-{ }^{32} \mathrm{P}\right]$ deoxycytidine triphosphate $\left(\left[\alpha{ }^{32} \mathrm{P}\right] \mathrm{dCTP} ; \sim 3000 \mathrm{Ci} / \mathrm{mM}\right)$ was purchased from DuPont NEN (Boston, MA). Other reagents for RT-PCR and tissue culture were of molecular biology grade and tissue culture grade, respectively, and were obtained from commercial sources. Plasmids containing the full-length cDNA inserts for rat NR2A and NR2C were provided by Dr. S. Nakanishi (Kyoto University Faculty of Medicine, Kyoto, Japan), and plasmid containing the full-length CDNA insert for rat NR2B was provided by Dr. J. Sullivan (The Salk Institute, San Diego, CA).

Tissue cullure. Granule cell-enriched cultures were obtained essentially as described by Levi et al. (1989) and characterized previously in our laboratory (Leahy et al., 1994). Because of their unique postnatal pattern of migration compared with other neuronal types, highly enriched preparations of granule cells $(>95 \%)$ using 7 - to 9-d-postnatal rodent cerebellum as a tissue source can be obtained for study. Briefly, cerebella from postnatal day 8 (PN8) Sprague-Dawley rats were minced, trypsinized, and triturated to dissociate cells. The cells were plated at a density of $2-4 \times 10^{6}$ cells $/ 2 \mathrm{ml}$ medium onto $35 \mathrm{~mm}$ plastic dishes coated with $10 \mu \mathrm{g} / \mathrm{ml}$ poly-L-lysine and incubated at $37^{\circ} \mathrm{C}$ in a humidified atmosphere of $5 \% \mathrm{CO}_{2} / 95 \% \mathrm{O}_{2}$. Cultures were supplemented with $10 \mu \mathrm{M}$ cytosine arabinoside $24 \mathrm{hr}$ after plating to prevent proliferation of nonneuronal cells, and the medium was renewed $48 \mathrm{hr}$ after plating. Cell viability was monitored daily using phase-contrast microscopy as described previously (Leahy et al., 1994). The standard growth medium consisted of basal Eagle's medium with Earle's salts supplemented with (final concentrations) heat-inactivated fetal calf serum (10\%), gentamicin $(100 \mu \mathrm{g} / \mathrm{ml})$, L-glutamine $(2 \mathrm{~mm})$, and $\mathrm{KCl}(5$ or $25 \mathrm{mM})$ or $100 \mu \mathrm{M}$ NMDA $+15 \mathrm{~mm} \mathrm{KCl}$. The trophic effect of NMDA on cell survival is enhanced when NMDA is used in combination with concentrations of $\mathrm{KCl}(10-15 \mathrm{~mm})$ that are ineffective alone but that presumably enhance the stimulatory effect of NMDA on $\mathrm{Ca}^{2+}$ influx by relieving the $\mathrm{Mg}^{2+}$ block on the receptor channel (Gallo et al., 1987; Balazs et al., 1988a; Didier et al., 1989; Moran and Patel, 1989).

$R N A$ isolation. Whole-cell RNA was isolated from cerebellar granule cells in culture (0-14 DIV) or from whole rat hippocampus and cerebellum (PN0, PN7, PN12, and PN19) by the guanidinium-isothiocyanate method described by Chomczynski and Sacchi (1987). After the final ethanol precipitation, the RNA pellet was suspended in sterile water. The concentration and purity of RNA were assessed with a spectrophotometer using nucleotide absorption at $260 \mathrm{~nm}$, and ratio at $260 / 280 \mathrm{~nm}$ (nucleotide/protein), respectively.

$R T$. Whole-cell RNA was used in an RT reaction to produce cDNA for use as template in PCR (Lambolez et al., 1992). Initially, 0.1-0.2 $\mu \mathrm{g}$ of RNA in $4 \mu \mathrm{l}$ of sterile $\mathrm{H}_{2} \mathrm{O}$ was heated to $94^{\circ} \mathrm{C}$ for $1 \mathrm{~min}$ and then cooled on ice. Six microliters of a mixture containing (final concentrations) MMLV RT (100 U), RT buffer ( $50 \mathrm{~mm}$ Tris- $\mathrm{HCl}, \mathrm{pH} 8.3,75 \mathrm{~mm} \mathrm{KCl}, 3$ $\mathrm{mM} \mathrm{MgCl}_{2}$ ), dithiothreitol (10 $\left.\mathrm{mm}\right)$, the four dNTPs (0.5 mM each), RNasin ribonuclease inhibitor $(20 \mathrm{U})$, and hexamer random primers (5 $\mu \mathrm{M}$ ) wcre added to cach RNA sample (final volume, $10 \mu \mathrm{l}$ ). Use of a random primer rather than oligo(dT) minimizes the effect of sequence complexity, mRNA secondary structure, and distance of primer sequence from the polyA ${ }^{+}$tail (Noonan and Roninson, 1988). The $\mathrm{RT}$ reaction was initiated by incubation at $37^{\circ} \mathrm{C}$ for $60 \mathrm{~min}$ to promote synthesis of cDNA and then terminated by placing tubes on ice and diluting to $0.1-5.0 \mathrm{ng} / \mu \mathrm{l}$ using sterile $\mathrm{H}_{2} \mathrm{O}$. In some cases, the RT reaction was performed in the absence of either RT or RNA as controls.

$P C R$. After RT, PCR of NR2A, NR2B, and NR2C subunit-specific mRNAs was performed as described previously by Audinat et al. (1994) in a final volume of $100 \mu \mathrm{l}$ containing cDNA derived from $0.1-5.0 \mathrm{ng}$ of input RNA and the following components (final concentrations): Taq buffer ( $10 \mathrm{~mm}$ Tris- $\mathrm{HCl}$, pH $8.8,50 \mathrm{mM} \mathrm{KCl}, 1.5 \mathrm{~mm} \mathrm{MgCl}_{2}, 0.001 \%$ gelatin); the four dNTPs (0.5 mM each); oligonucleotide primers upstream (5'-GGGGTTCTGCATCGACATCC-3', sense, complete match with NR2A, two mismatches with NR2B, one mismatch with NR2C) and downstream (5'-GACAGCAAAGAAGGCCCACAC-3', antisense, com- plete match with NR2A and NR2B, one mismatch with NR2C) (10 pM each); and $T a q$ polymerase $(2.5 \mathrm{U})$. The samples were overlaid with 2 drops of mineral oil to prevent evaporation during the temperature cycling. Before PCR, samples were heated to $94^{\circ} \mathrm{C}$ for 2 min. PCR was performed in a Perkin-Elmer Model 480 Tempcycler (Emeryville, CA) as follows: five cycles at $94^{\circ} \mathrm{C}$ for $30 \mathrm{sec}$; at $48^{\circ} \mathrm{C}$ for $30 \mathrm{sec}$; ramp to $72^{\circ} \mathrm{C}$ for $1 \mathrm{~min} 10 \mathrm{sec} ; 72^{\circ} \mathrm{C}$ for $30 \mathrm{sec}$ followed by 35 cycles at $94^{\circ} \mathrm{C}$ for $30 \mathrm{sec} ; 53^{\circ} \mathrm{C}$ for $30 \mathrm{sec}$; and $72^{\circ} \mathrm{C}$ for $36 \mathrm{sec}$. After PCR, samples were heated to $72^{\circ} \mathrm{C}$ for $5 \mathrm{~min}$. Typically, equal aliquots of the samples were digested subse quently with $\mathrm{H}_{2} \mathrm{O}$ or each of the three restriction enzymes to obtain a measure of (1) total uncut $547 \mathrm{bp}$ template $\left(\mathrm{H}_{2} \mathrm{O}\right)$ and partial uncut template plus fragments corresponding to (2) NR2A (BpmI), (3) NR2B $(B f a \mathrm{I})$, and (4) NR2C $\left(S_{c a} \mathrm{I}\right)$. The reaction was performed in a final volume of $10 \mu \mathrm{l}$ as follows. After PCR, four $5 \mu \mathrm{l}$ aliquots from each PCR sample tube were placed in four sterile tubes and maintained at $4^{\circ} \mathrm{C}$. 'To each of the four tubes were added the following: (1) $5 \mu$ l of sterile $\mathrm{H}_{2} \mathrm{O}$ or $3 \mu$ l of sterile $\mathrm{H}_{2} \mathrm{O}+1 \mu \mathrm{l}$ of supplied buffer $+1 \mu \mathrm{l}$ of (2) BpmI ( $2 \mathrm{U}$ ), (3) BfaI (5 U), and (4) ScaI (10 U). After incubation at $37^{\circ} \mathrm{C}$ for $60 \mathrm{~min}$ to produce complete digestion, samples were resolved on $1.5 \%$ ethidium bromide-stained agarose or $8 \%$ polyacrylamide gels, to separate and visualize the different size fragments, and then were photographed while illuminated with ultraviolet (UV) light. The units of restriction enzymes used in the digestion reaction were determined to be saturating for the range of amplicons tested. The fragments produced after digestion were shown by Southern blotting analysis to be derived from the appropriate NR2 subunit-specific cDNAs (Audinat et al., 1994). To ensure that equivalent efficiencies of amplification for all three NR2 cDNAs proceeded under the conditions of assay, known quantities of plasmids containing NR2A, NR2B, or NR2C cDNA inserts were linearized with Not I and subsequently were used in the PCR assay, alone or in various combinations to compare the proportions of amplified products with the initial proportions added.

PCR amplification of NR1 was similar to that described for NR2 with the following modifications. The oligonucleotide primers were upstream (5'-CTCCCACCAGTCCAGCGTCT-3', sense) and downstream (5'GTCATGTTCAGCATTGCGGC-3', antisense), specifying amplicons of 288 and $354 \mathrm{bp}$, corresponding to mRNAs lacking or containing exon 5 and designated as NR1a and NR1b, respectively. Before PCR, samples were heated to $94^{\circ} \mathrm{C}$ for $2 \mathrm{~min}$. PCR was performed in a Perkin-Elmer Model 480 Tempcycler as follows: 40 cycles at $94^{\circ} \mathrm{C}$ for 30 sec, at $60^{\circ} \mathrm{C}$ for $30 \mathrm{sec}$, and at $72^{\circ} \mathrm{C}$ for $60 \mathrm{sec}$. After PCR, samples were heated to $72^{\circ} \mathrm{C}$ for $5 \mathrm{~min}$. Samples were resolved on $1.5 \%$ ethidium bromide-stained agarose gels to separate and visualize amplicons corresponding to NRla and NR1b, and then photographed while illuminated with UV light.

For several cell preparations, the assays were repeated in the presence of radiolabeled nucleotide to estimate the relative proportion of NR mRNAs. This was accomplished by adding a trace amount of $\left[\alpha^{-}{ }^{32} \mathrm{P}\right] \mathrm{dCTP}(2 \mu \mathrm{Ci}, 0.66 \mathrm{pmol})$ to each PCR reaction tube, replacing $\mathrm{H}_{2} \mathrm{O}$. After the PCR assay, products were separated on agarose gels, and gel pieces containing uncut template or restriction-digested template were excised while visualizing the ethidium bromide-stained fragments under UV illumination. Radioactivity was quantitated in a liquidscintillation system using the tritium window and Cerenkov radiation. For each of the four gel lanes derived from a given sample after NR2 RT-PCR and incubation with the appropriate restriction enzyme, the sums of the digested fragments plus the remaining uncut amplicon (corresponding to the contribution of the other two NR' 2 mRNAs) were comparable. Data are expressed as mean \pm SEM percentages of total recovered amplicon. Mean recovery of NR2 fragments after amplicon digestion with restriction enzymes was $>85 \%$ compared with total uncut amplicon.

\section{RESULTS}

\section{Fidelity of the NR2 RT-PCR assay}

To specify amplification of NR2A, NR2B, and NR2C cDNAs, oligonucleotide primers were selected in a common coding region and restriction enzymes recognizing unique sequences within NR2A $(B p m I)$, NR2B (BfaI), and NR2C (ScaI) were used to assess the relative proportion of cach transcript in the total amplified template. Figure $1 A$ depicts the approximate position of the amplified region within the coding sequence and also indicates the predicted sizes of the two fragments derived from amplicon cleavage with each restriction enzyme. Figure $1 B(l e f t)$ is a pho- 
A

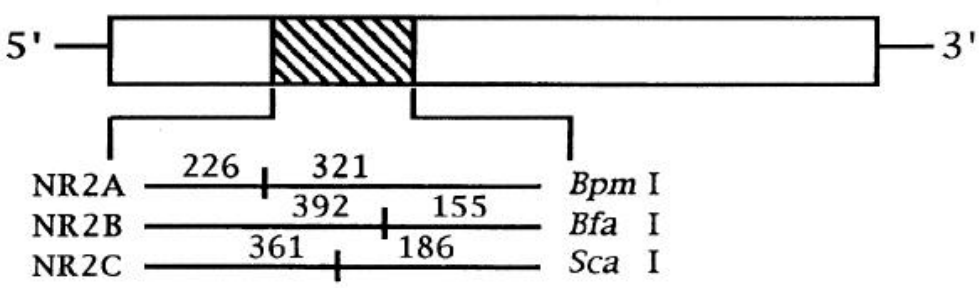

B

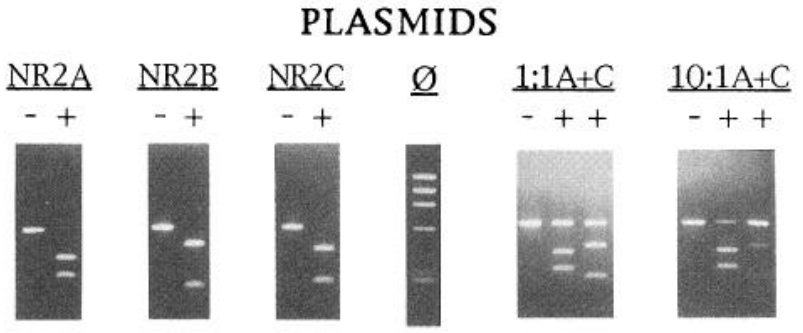

C

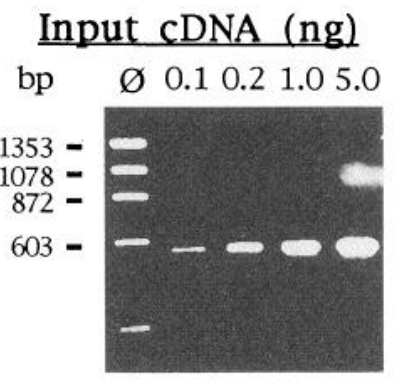

Figure 1. RT-PCR analysis of NR2A, NR2B, and NR2C subunit-specific mRNAs. $A$, Schematic diagram delineating the approximate region in the common coding sequence of all three NR2 subunit cDNAs (hatched segment) specified by oligonucleotide primers. Their respective positions (NR2A, NR2B, NR2C) were 1370, 1373 , or 1364 (sense) and 1896, 1899, or 1890 (antisense). The predicted fragment size derived after cleavage of each specific amplicon with its corresponding restriction enzyme is shown below. $B$, Ethidium bromide-stained agarose gels $(1.5 \%)$ depicting total uncut $547 \mathrm{bp}$ amplicon obtained after PCR amplification of linearized plasmids containing NR2A, NR2B, or NR2C alone (left) or NR2A $+\mathrm{NR} 2 \mathrm{C}$ in $1: 1(1: 1 A+C)$ or 10:1 $(10: 1 A+C)$ ratio (right), respectively (the use of radiolabeled nucleotide during PCR ensured that the proportion of radiolabeled amplicons was in accordance with the proportion of input cDNAs), and specific cleavage fragments derived from incubation of an aliquot of amplicon in the presence $(+)$ or absence (-) of BpmI (for NR2A), BfaI (for NR2B), and $S c a$ I (for NR2C). No cleavage product was observed when plasmid was incubated with one of the other restriction enzymes (data not shown). The gel lanes marked $\varnothing$ represent the molecular-weight marker HaeIII digest of $\varnothing \mathrm{X} 174$ that was used as a standard. $C$, Ethidium bromidestained agarose gel $(1.5 \%)$ depicting the amount of $547 \mathrm{bp}$ amplicon produced when $0.1,0.2,1.0$, or $5 \mathrm{ng}$ of input RNA from cerebellar granule cells was used in the RTPCR assay. The gel lane marked $\varnothing$ represents the molecular-weight marker HaeIII digest of $\varnothing \mathrm{X} 174$ that was used as a standard, with sizes (in $b p$ ) of several constituent cleavage products shown on the left. tograph of an ethidium bromide-stained agarose gel depicting the products obtained after PCR amplification of linearized plasmids containing inserts for NR2A, NR2B, or NR2C. Equal aliquots of samples containing each of the three amplicons were incubated in the presence $(+)$ or absence $(-)$ of their corresponding restriction enzyme. In each case, a 547 bp amplicon that was digested completely with the appropriate restriction enzyme yielding two fragments of the predicted size was obtained.

The strategy of designing oligonucleotide primers that recognize homologous sequences in the three NR2 cDNAs to produce an amplicon corresponding to the sum of NR2A, NR2B, and NR2C in a sample of total cell RNA simplifies the PCR protocol because a common pair of primers is used. Because there are one or two mismatches between the primers and the complementary sequences in NR2B and NR2C, however, known quantities of plasmids were coamplified in the presence of $\left[\alpha-{ }^{32} \mathrm{P}\right] \mathrm{dCTP}$ and were quantified to verify that a greater efficiency of amplification of one (i.e., NR2A) or more cDNAs did not occur under the conditions of assay. Preferential amplification of NR2A, NR2B, or NR2C cDNA was not observed when levels of input cDNAs for the different transcripts were varied over a 10 -fold range (Fig. $1 B$, right).

To compare levels of NR2 subunit-specific mRNAs accurately in a given sample of total cellular RNA, the cycle number and the amount of input RNA were adjusted in accordance with the relative abundance of these transcripts and the efficiency of the PCR. Figure $1 C$ is a photograph of an ethidium bromide-stained agarose gel depicting the amount of amplicon produced when
cDNA derived from $0.1,0.2,1.0$, or $5 \mathrm{ng}$ of input RNA from granule cells was used in the PCR assay. On this basis, 0.5-2.0 ng of input RNA typically was used in the NR2 PCR assay to enable adequate visualization of amplicons and derivative fragments on ethidium bromide-stained gels.

The reliability of the NR2 RT-PCR assay was evaluated further in PN7 and PN12 rat hippocampus and cerebellum, which provided data for direct comparison with previously published in situ hybridization analysis of NR2 mRNAs at PN7 and PN12 (Monyer et al., 1992, 1994; Watanabe et al., 1992, 1994). In situ data indicate that NR2B and NR2D mRNAs are expressed widely in embryonic but not adult neurons, whereas NR2A is the most abundant message in adult forebrain and NR2C is highly enriched in and largely restricted to the granule-cell layer in adult cerebellar cortex. Figure 2, $A$ and $B$, shows photographs of ethidium bromide-stained agarose gels depicting the total amount of amplicon (lane $T$ ) and fragments derived by digestion of equal aliquots of the amplicon with different restriction enzymes specific for NR2 (lanes $A-C$ ) corresponding to the relative proportions of mRNAs in PN7 or PN12 hippocampus and cerebellum. In each sample, amplified 547 bp product, representing the sum of NR2A $+\mathrm{NR} 2 \mathrm{~B}+\mathrm{NR} 2 \mathrm{C}$ in a given sample of input RNA, was the major product obtained. As expected, both brain regions expressed significant levels of NR2B mRNA at PN7, whereas NR2A and NR2C were the most abundant transcripts in hippocampus (Fig. $2 A$ ) or cerebellum (Fig. $2 B$ ), respectively, at PN12. Similar proportions of NR2 mRNAs were observed over a range of input RNAs (0.2-1.0 ng). 
A

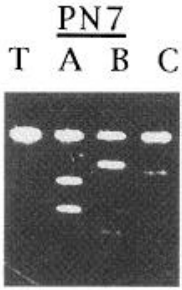

B

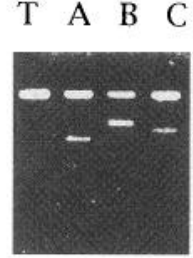

T A B C

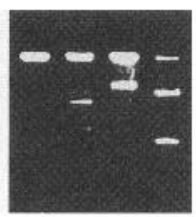

Figure 2. Pattern of NR2A, NR2B, and NR2C mRNA expression in rat hippocampus and cerebellum. Whole-cell RNA was harvested from rat hippocampus $(A)$ or cerebellum $(B)$ at $P N 7$ or $P N 12$. RNA was reversetranscribed to produce cDNA template that was amplified subsequently by PCR using NR2-specific primers. Equal aliquots of amplified samples were incubated in the absencc (lane T) or presence of BpmI (lane A), BfaI (lane B), or ScaI (lane C) for $1 \mathrm{hr}$ at $37^{\circ} \mathrm{C}$, resolved on ethidium bromidestained agarose gels (1.5\% agarose), and photographed under UV illumination. (Note: the lower-molecular-mass fragment derived from amplicon cleavage was not always sufficiently abundant to permit visualization on ethidium bromide-stained gels.)

\section{Induction of NR2A and NR2C and downregulation of NR2B mRNAs by $25 \mathrm{~mm} \mathrm{KCl}$ or NMDA}

Primary cultures of cerebellar granule cells were maintained for 4-14 DIV in the presence of $25 \mathrm{~mm} \mathrm{KCl}$. Whole-cell RNA was harvested before plating cells (0 DIV) or after increasing DIV, and RT-PCR was performed. Figure $3 A$ is an ethidium bromidestained polyacrylamide gel depicting the amplified cDNAs corresponding to total NR2, and NR2A, NR2B, or NR2C mRNAs at 0 DIV. The relative proportions of NR2 mRNAs at 0 DIV were estimated by repeating the assay in the presence of $\left[\alpha-{ }^{32} \mathrm{P}\right] \mathrm{dCTP}$. In five separate cell preparations examined, NR2B was the predominant transcript, with lower, but detectable, levels of NR2A and NR2C (NR2A, $19.0 \pm 2.5 \%$; NR2B, $63.2 \pm 5.6 \%$; NR2C, 17.8 $\pm 4.7 \% ; n=5$ ). After 5-7 DIV in the presence of $25 \mathrm{~mm} \mathrm{KCl}$, cells demonstrated the morphological features of the differentiated phenotype with elaborate neurite processes interconnecting groups of cell clusters, as verified using phase-contrast microscopy. Figure $3 B$ is an ethidium bromide-stained gel depicting the total amount of $547 \mathrm{bp}$ amplicon (lane $T$ ) and the corresponding amounts of NR2A, NR2B, or NR2C mRNAs expressed in the same preparation of cells after 5 or $10 \mathrm{DIV}$. The predominant transcript after 5 DIV is NR2A. After 10 DIV, similar amounts of NR2A and NR2C mRNAs were expressed, with no apparent change in the total amount of $547 \mathrm{bp}$ amplicon. Simultaneous digestion with all three restriction enzymes (Fig. $3 B$, lanes $A-C$ ) produced fragments corresponding to NR2A and NR2C mRNAs, with no remaining uncut amplicon. No template was observed in the absence of added RNA or RT (data not shown). In 6 of 6 cell preparations performed on different litters, the predominant transcript in cells examined at 4-5 DIV was NR2A, with barely detectable levels of NR2B and undetectable levels of NR2C. In 7 of 9 different cell preparations examined at 7-14 DIV, the amounts of NR2B mRNA were below the limits of detection, and levels of NR2C gradually increased and often became the predominant transcript. In 2 of 9 cell preparations examined at 7-14
A

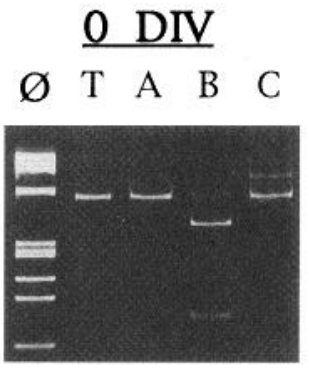

B
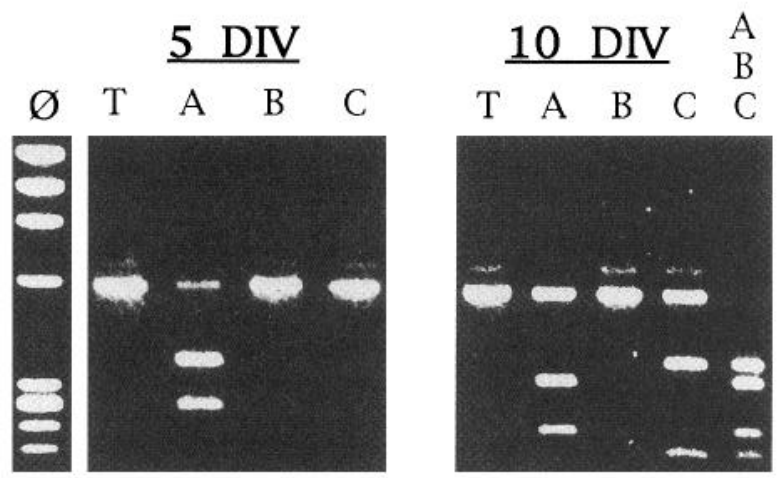

Figure 3. Pattern of expression of NR2A, NR2B, and NR2C mRNAs in freshly dissociated cerebellar granule cells or cells cultured in $25 \mathrm{~mm}$ $\mathrm{KCl}$-containing media. $A$, Whole-cell RNA was harvested from granulecell preparations at $O D I V$ and processed for RT-PCR as described in the legend for Figure 2. Equal aliquots of amplified samples were incubated in the absence (lane $T$, total uncut amplicon) or presence of BpmI (lane A), $B f a \mathrm{I}$ (lane $B$ ), or ScaI (lane $C$ ), resolved on ethidium bromide-stained polyacrylamide gel $(8 \%)$, and photographed under UV illumination. The identity of the minor band migrating above the uncut amplicon in lane $C$ is unknown, but it was not detected in the other preparations examined. The gel lane marked $\varnothing$ represents the molecular-weight marker HaeIII digest of $\varnothing \mathrm{X} 174$ that was used as a standard. (Note: the fragments derived from amplicon cleavage were not always sufficiently abundant to permit visualization on ethidium bromide-stained gels.) $B$, Whole-cell RNA was harvested from the same granule-cell preparation at $5 \mathrm{DIV}$ and $10 \mathrm{DIV}$ and processed for RT-PCR as described above, except that samples were resolved on agarose gels. The gel lane marked $A B C$ corresponds to a sample that was digested with all three restriction enzymes simultaneously. A minor band migrating just above the 547 bp amplicon was observed in several granule-cell preparations and was specifically cleaved by BpmI. The identity of this minor amplicon remains to be determined. The gel lane marked $A B C$ represents the molecular-weight marker HaeIII digest of $\varnothing \mathrm{X} 174$ that was used as a standard.

DIV, NR2A remained the predominant transcript, with low levels of NR2C and no NR2B. Although the onset of NR2C mRNA expression was variable among cultures (7-10 DIV), once induced, levels increased gradually with increasing DIV. Longer times in culture were not examined because cells deteriorate by 16-18 DIV. The relative proportions of NR2 mRNAs in cultures chronically exposed to $25 \mathrm{~mm} \mathrm{KCl}$ were estimated by repeating the assay in the presence of $\left[\alpha-{ }^{32} \mathrm{P}\right] \mathrm{dCTP}$. In three separate cell preparations examined at 4-5 DIV, NR2A was the predominant transcript ( $>95 \%$ of total), with low, but detectable, levels of NR2B and no detectable NR2C. In six separate cell preparations examined at 12-14 DIV, levels of NR2A and NR2C were comparable and NR2B was undetectable (NR2A, $46.8 \pm 7.4 \%$; NR2C, $49.5 \pm 7.8 \% ; n=6$ ). 
A
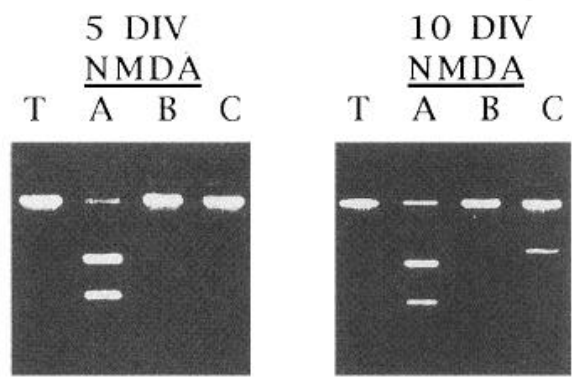

B
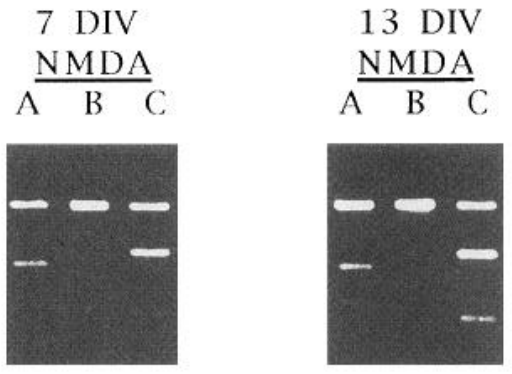

Figure 4. Pattern of expression of NR2A, NR2B, and NR2C mRNAs in developing cerebellar granule cells cultured in NMDA-containing media. At the time of plating, cells were cultured in the continued presence of 100 $\mu \mathrm{M}$ NMDA $+15 \mathrm{mM} \mathrm{KCl}$. Whole-cell RNA was harvested from the same granule-cell preparation at $5 \mathrm{DIV}$ and $10 \mathrm{DIV}(\mathrm{A})$ or from a different granule-cell preparation at $7 \mathrm{DIV}$ and $13 \mathrm{DIV}(B)$ and processed for RT-PCR as described in the legend for Figure 2. After PCR, equal aliquots of amplified samples were incubated in the absence (lane $T$ ) or the presence of BpmI (lane A), Bfa I (lane B), or ScaI (lane C), resolved on ethidium bromide-stained agarose gels, and photographed under UV illumination. Samples representing total uncut amplicon (lane $T$ ) were not performed in the experiment shown in $B$.

To determine whether NMDA substitutes effectively for $25 \mathrm{~mm}$ $\mathrm{KCl}$ in promoting expression of NR2A and NR2C subunit mRNAs and downregulating NR2B mRNA, a series of experiments was performed using cells cultured in $100 \mu \mathrm{M}$ NMDA/15 $\mathrm{mm} \mathrm{KCl}$. Figure $4 A$ is an ethidium bromide-stained gel demonstrating the total amount of uncut amplicon (lane T) and the relative proportions of NR2A, NR2B, and NR2C mRNAs at an early (5 DIV) and later (10 DIV) stage of granule-cell development. Similar to cells cultured in $25 \mathrm{~mm} \mathrm{KCl}$, NR2A was the predominant transcript at 5 DIV, whereas NR2C expression became apparent by 10 DIV. Figure $4 B$ depicts the relative levels of mRNAs corresponding to NR2A, NR2B, and NR2C in a different cell preparation in which $\mathrm{NR} 2 \mathrm{C}$ mRNA expression was induced at an earlier time. By 7 DIV, NR2C mRNA was the predominant transcript, and it remained predominant compared with NR2A at 13 DIV. NR2B mRNA was below the limits of detection at both stages. In this preparation, NR2A was the most abundant transcript, and a minor amount of NR2B was detectable at 5 DIV (data not shown). Qualitatively similar results were obtained in 3 of 3 cell preparations examined at 4-5 DIV and in 5 of 5 cell preparations examined at 7-14 DIV. These data indicate that the earliest detectable NR alterations in neurons cultured in the presence of $25 \mathrm{~mm} \mathrm{KCl}$ or NMDA are an increase in NR2A and decreases in NR2B and NR2C mRNAs compared with freshly dissociated cells examined at 0 DIV. With increasing DIV, there is a gradual increase in expression of NR2C mRNA, whereas NR2B mRNA becomes undetectable.

\section{Expression of NR2 mRNAs in the presence of $5 \mathrm{~mm} \mathrm{KCl}$}

Previous reports indicate that cells cultured in $5 \mathrm{~mm} \mathrm{KCl}$ preferentially respond to non-NR ligands as opposed to NR ligands (Cox et al., 1990; Van der Valk et al., 1991), suggesting that NRs are downregulated or are not expressed under these conditions, which have been designated to be "activity-independent." To determine the activity dependence of NR2A, NR2B, and NR2C mRNA expression, granule cells were cultured in 5 or $25 \mathrm{~mm} \mathrm{KCl}$. RNA was harvested after different periods of time and subjected to RT-PCR. Cell survival and differentiation are compromised in $5 \mathrm{~mm} \mathrm{KCl}$, and phase-contrast microscopic analysis showed significant and progressive cell deterioration beginning at $\sim 6-7$ DIV. Accordingly, recovery of whole-cell RNA in six different granule-cell preparations extracted at $10-14$ DIV in $5 \mathrm{~mm} \mathrm{KCl}$ was $33.0 \pm 2.8 \%$ (mean $\pm \mathrm{SEM}$ ) compared with cells cultured in $25 \mathrm{~mm} \mathrm{KCl}(100 \%$, paired cultures). Figure $5 A$ shows an ethidium bromide-stained gel comparing the total amount of uncut amplicon (lane T) and the relative proportions of NR2A, NR2B, and NR2C mRNAs at an early (5 DIV) and later (10 DIV) stage of granule-cell development in 5 or $25 \mathrm{~mm} \mathrm{KCl}$. With $5 \mathrm{~mm} \mathrm{KCl}$, NR2A is the predominant transcript at 5 DIV and significant levels of NR2B mRNA also are expressed compared with cells cultured in $25 \mathrm{~mm} \mathrm{KCl}$. Increased levels of NR2B transcript in cells cultured in $5 \mathrm{~mm} \mathrm{KCl}$ were observed in three of four preparations compared with cells cultured in $25 \mathrm{~mm} \mathrm{KCl}$ or NMDA. By 10 DIV, cells cultured in 5 or $25 \mathrm{~mm} \mathrm{KCl}$ were indistinguishable with respect to total amplicon and pattern of NR2 mRNA expression, with high levels of both NR2A and NR2C mRNAs and no detectable NR2B mRNA. In another cell preparation, both NR2A and NR2C mRNAs, but not NR2B mRNAs, were detectable in $5 \mathrm{~mm} \mathrm{KCl}$ cells at 7 DIV and, similar to cells cultured in the presence of $25 \mathrm{~mm} \mathrm{KCl}$, NR2C was the predominant transcript at 13 DIV (Fig. $5 B$ ). In this preparation, NR2A was the most abundant transcript, and a small amount of NR2B was detectable at 5 DIV under both conditions (data not shown). Prominent expression of NR2C mRNA was observed in 7 of 7 cell preparations cultured in $5 \mathrm{~mm} \mathrm{KCl}$ and examined at 7-14 DIV. The relative proportions of NR2 mRNAs in paired cultures chronically exposed to 5 or $25 \mathrm{~mm} \mathrm{KCl}$ were estimated in five separate cell preparations at $9-12$ DIV by including $\left[\alpha-{ }^{32} \mathrm{P}\right] \mathrm{dCTP}$ in the PCR assay. In each case, the amounts were comparable with similar levels of NR2C and NR2A and undetectable levels of NR2B (5 mм KCl: NR2A, $46.8 \pm 7.2 \%$; NR2C, $50.1 \pm 7.8 \% ; 25$ mм KCl: NR2A, $51.1 \pm 8.6 \%, \mathrm{NR} 2 \mathrm{C}, 47.5 \pm 9.2 \% ; n=5$ ). These data indicate that the granule cells that survive after 9-12 DIV in $5 \mathrm{~mm} \mathrm{KCl}$ express similar proportions of NR2 mRNAs for a given amount of input RNA compared with cells cultured in $25 \mathrm{~mm} \mathrm{KCl}$.

\section{Induction of NR1b mRNA by $5 \mathrm{~mm}$, but not $25 \mathrm{~mm}, \mathrm{KCl}$ or NMDA}

Granule cells demonstrate a pronounced developmental increase in the ratio of the NR1b variant containing an N-terminal insertion encoded by exon 5 , compared with NR1a, which lacks exon 5 ( $\sim 10$-fold compared with adult rat forebrain neurons) (Nakanishi et al., 1992; Della Vedova et al., 1994; Laurie and Seeburg, 1994). NRs containing NR1b exhibit altered sensitivities to several potentially important modulators of NR responsiveness compared with NRs containing NR1a (McBain and Mayer, 1994). To evaluate the effects of neuronal activity on induction of NR1b in granule-cell cultures, an RT-PCR assay was developed to distinguish between NR1a and NR1b mRNAs. The oligonucleotide 
Figure 5. Pattern of expression of NR2A, NR2B, and NR2C mRNAs in developing cerebellar granule cells cultured in media containing $5 \mathrm{~mm} \mathrm{KCl}$ or $25 \mathrm{~mm} \mathrm{KCl}$. At the time of plating, cells were cultured in the continued presence of $5 \mathrm{mM} \mathrm{KCl}$ or $25 \mathrm{~mm} \mathrm{KCl}$. Whole-cell RNA was harvested from the same granule-cell preparation at $5 \mathrm{DIV}$ and $10 \mathrm{DIV}(A)$ or from a different granule-cell preparation at $7 \mathrm{DIV}$ and $13 \mathrm{DIV}(B)$ and processed for RT-PCR as described in the legend for Figure 2. After PCR, equal aliquots of amplified samples were incubated in the absence (lane $T$ ) or presence of BpmI (lane A), BfaI (lane B), or ScaI (lane $C$ ), resolved on ethidium bromide-stained agarose gels, and photographed under UV illumination. Samples representing total uncut amplicon (lane $T$ ) were not performed in the experiment shown in $B$.
A

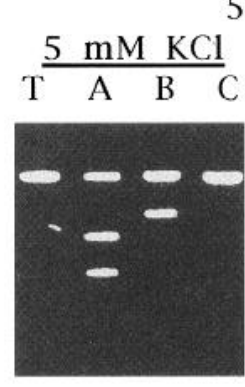

5 DIV

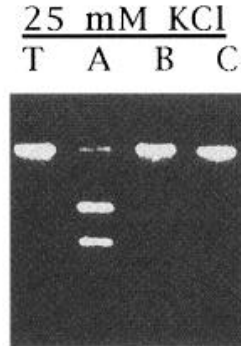

B

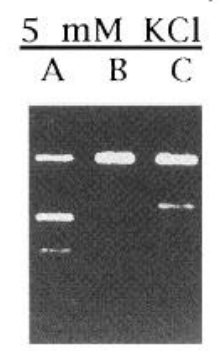

10 DIV
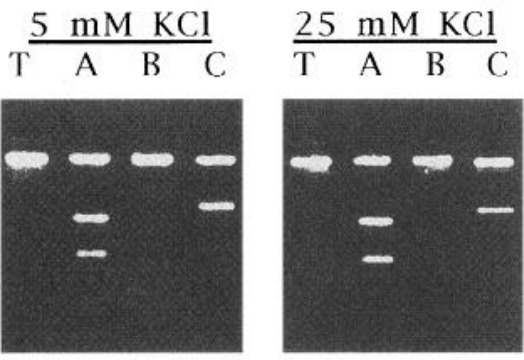

13 DIV

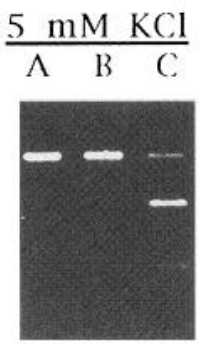

$\underline{25 \mathrm{mM} \mathrm{KCl}}$ $\wedge$ B C

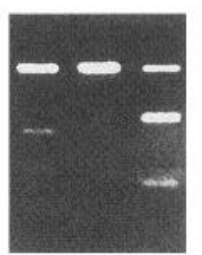

primers recognize sequences in the $\mathrm{N}$-terminal coding region of NR1, including the region containing exon 5 in NR1b, and specify amplicons of 354 bp (NR1b, + exon 5) or 288 bp (NR1a, - exon 5). To verify the reliability of the RT-PCR assay, the proportions of NR1a and NR1b in whole-tissue RNA derived from PN0 or PN19 rat cerebellum were compared. Figure $6 A$ is a photograph of an ethidium bromide-stained agarose gel demonstrating that amplicons of 288 and 354 bp corresponding to NR1a and NR1b mRNAs, respectively, were the major products obtained. The predicted developmental increase in NR1b compared with NR1a was observed between PN0 and PN19. Similar results were obtained in three other preparations, including adult cerebellum and hippocampus, which contained predominantly NR1b and NR1a mRNAs, respectively (data not shown). No product was visible in the absence of added RNA or RT, and the proportions of NR1 variants were maintained over the range of input RNAs used in the assay (data not shown). Next, the influence of time in culture (4-5 vs 10-14 DIV) and activity (5 or $25 \mathrm{~mm} \mathrm{KCl}$ or NMDA/15 mм $\mathrm{KCl}$ ) on expression of NR1a and NRlb were compared. At 4-5 DIV under the three conditions of cell culture, NR1a mRNA predominated, whereas NR1b made up $<10 \%$ of the total NR1 transcript (\%NR1b/NR1a + NR1b: $5 \mathrm{~mm} \mathrm{KCl,} 6.8 \pm 2.8 \%, n=$ $6 ; 25 \mathrm{~mm} \mathrm{KCl}, 5.2 \pm 1.1 \%, n=9 ; \mathrm{NMDA} / 15 \mathrm{~mm} \mathrm{KCl}, 0.4 \pm 0.4 \%$, $n=3)$. In contrast, a gradual induction of NR1b was observed in older cultures grown in $5 \mathrm{~mm} \mathrm{KCl}$ compared with cells cultured in $25 \mathrm{~mm} \mathrm{KCl}$ or NMDA/15 mM KCl, with no apparent change in the level of total NR1 transcript (Fig. 6B). Whole-cell RNAs extracted from several cell preparations at 10-14 DIV were assayed in the presence of $\left[\alpha^{-32} \mathrm{P}\right] \mathrm{dCTP}$, and NR1 variants were quantified (\%NR1b/NR1a + NR1b: $5 \mathrm{~mm} \mathrm{KCl,} 39.9 \pm 5.4 \%, n=5 ; 25 \mathrm{~mm}$ $\mathrm{KCl}, 11.2 \pm 2.4 \%, n=9 ; \mathrm{NMDA} / 15 \mathrm{~mm} \mathrm{KCl}, 10.6+1.6 \%, n=$ 4). These data suggest that the greater levels of neuronal activity obtained with $25 \mathrm{~mm} \mathrm{KCl}$ or NMDA/ $15 \mathrm{~mm} \mathrm{KCl}$ inhibit expression of NR1b compared with cells cultured in $5 \mathrm{~mm} \mathrm{KCl}$ and in vivo cerebellum.

\section{DISCUSSION}

In addition to differences in receptor density (Tremblay et al., 1988; Monaghan et al., 1989) and second-messenger modifications
(Kutsuwada et al., 1992), regulated expression of NR subunits causing distinct heteromeric forms of the NR-channel complex contributes to the functional diversity of neuronal responses to glutamate (Moriyoshi et al., 1991; Ishii et al., 1993). Although important information about the differential responsiveness of distinct NRs has been learned from experiments using transfected cells and oocytes, an advantage of cultured neurons is the presence of native receptors and signal-transduction systems. This provides opportunities to examine the physiological properties of cells expressing distinct NRs and the influence of epigenetic factors such as neuronal activity on subunit expression. In this report, dissociated cerebellar granule-cell cultures were selected for study because chronic exposure to elevated $\mathrm{KCl}$ or NMDA promotes differentiation, survival, and further development of responsiveness to NMDA, which can be neurotoxic after $\sim 8$ DIV (Lasher and Zagon, 1972; Balazs et al., 1988a,b; Burgoyne et al., 1988; Lysko et al., 1989; Moran and Patel, 1989; Cox et al., 1990; Pearson et al., 1992). These culture conditions enhance $\mathrm{Ca}^{2+}$ influx and mimic activity of glutamatergic mossy-fiber input to granule cells (Balazs and Hack, 1990). Mossy fibers are not chronically active in vivo (Ito, 1984), however, and the neuronal differentiation observed in vitro appears to be premature (Gallo et al., 1987). Moreover, recent immunochemical (Condorelli et al., 1993; Hack et al., 1995) and electrophysiological (Kamboj et al., 1995) data suggest that chronic exposure of granule-cell cultures to $25 \mathrm{~mm} \mathrm{KCl}$ induces expression of an immature non-NR subunit not observed in situ or in $5 \mathrm{mM} \mathrm{KCl}$. Thus, although using media containing $25 \mathrm{~mm} \mathrm{KCl}$ or NMDA promotes survival and renders cells responsive to NMDA, the endogenous phenotype is not obtained. In contrast, cells grown in media containing $5 \mathrm{~mm} \mathrm{KCl}$ have been mostly ignored by investigators studying NR responses because substantial cell death is observed by $6-7$ DIV $(\sim 70 \%$; see Gallo et al., 1987), and NMDA/glycine-evoked currents are essentially undetectable (Van der Valk et al., 1991) (but see Irving et al., 1992). Inclusion of NR antagonists in the culture medium further reduces the limited cell survival in $5 \mathrm{~mm} \mathrm{KCl}$ (Balazs et al., 1988a), however, and death of significant numbers of granule cells is a natural component of neurogenesis in cerebellar cortex. These 
A

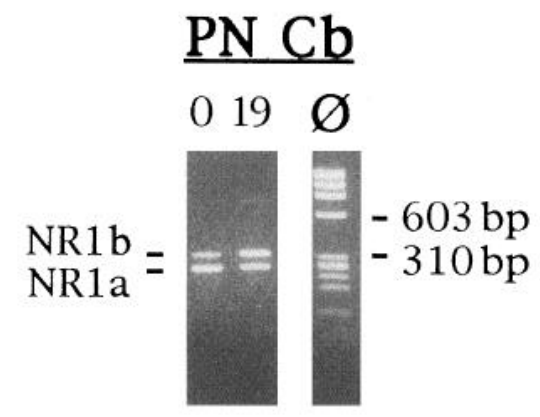

B

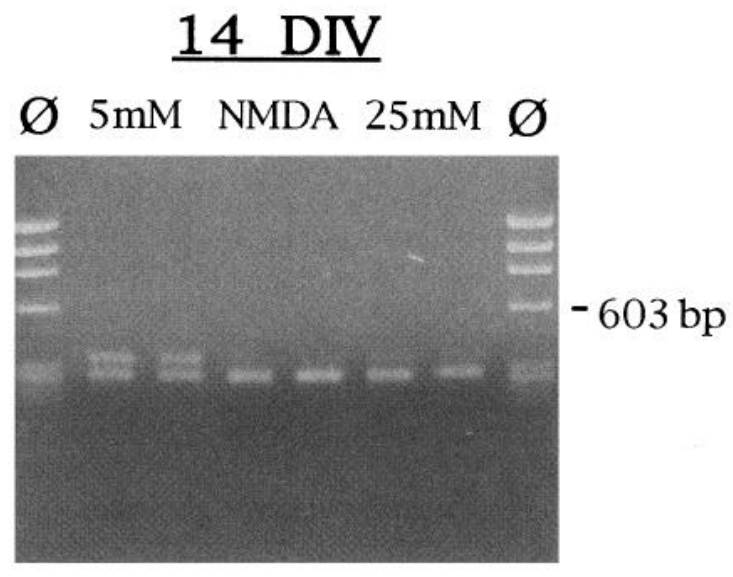

Figure 6. Induction of NR1b mRNA by $5 \mathrm{~mm}$, but not $25 \mathrm{~mm}, \mathrm{KCl}$ or NMDA. $A$, RNA was extracted from whole rat cerebellum $(P N C b)$ at PN0 $(0)$ and PN19 (19) and processed for RT-PCR as described in Materials and Methods. Ethidium bromide-stained agarose gel depicts amplicons of 288 and 354 bp corresponding to NR1a or NRIb mRNAs, respectively, at PN0 or PN19. The gel lane marked $\varnothing$ represents the molecular-weight marker HaeIII digest of $\varnothing \mathrm{X} 174$ that was used as a standard. B, Ethidium bromide-stained agarose gel depicting relative proportions of NR1a and NR1b mRNAs in cells cultured in $5 \mathrm{~mm} \mathrm{KCl}, 25 \mathrm{mM} \mathrm{KCl}$, or NMDA plus $15 \mathrm{~mm} \mathrm{KCl}$ (14 DIV: RNAs extracted from two separate culture dishes for each condition were assayed by RT-PCR and are shown). The gel lane marked $\varnothing$ represents the molecular-weight marker HaeIII digest of $\varnothing \mathrm{X} 174$ that was used as a standard.

observations indicate that ambient levels of glutamate acting on NRs are sufficient to support survival, and perhaps differentiation, of a subpopulation of cells grown in $5 \mathrm{~mm} \mathrm{KCl}$ and that the cell death observed at 6 DIV may recapitulate the naturally occurring process in vivo.

Levels of NR subunit mRNAs are positively correlated with levels of subunit protein (Sheng et al., 1994) and predicted electrophysiological properties of receptor channels composed of these subunits (Audinat et al., 1994; Farrant et al., 1994). Therefore, application of the highly sensitive RT-PCR methodology to NR subunit mRNAs in granule cells should provide pertinent information about the subunit composition of functional receptors. Initial studies verified that temporal and spatial differences in the pattern of expression of NR subunit mRNAs in whole hippocampus and cerebellum determined by RT-PCR (Figs. 2, 6A) were consistent with in situ hybridization data (Monyer et al., 1992, 1994; Watanabe et al., 1992, 1994). In situ granule-cell maturation is associated with the following: (1) prominent expression of NR2B mRNA during and downregulation of NR2B mRNA after migration from the external germinal to the internal granule layer, a process that begins shortly after birth and continues until PN21 (Ito, 1984); (2) induction of NR2A and NR2C mRNAs after the cells enter the internal granule layer; and (3) induction of NR1b, a spliced variant of NR1, containing an $\mathrm{N}$-terminal insertion such that the ratios of NR1b/NR1a mRNAs are $\sim 0.3: 1$ at birth, $\sim 1: 1$ at PN18-PN21, and $\sim 5: 1$ in adult cerebellum (Nakanishi et al., 1992; Della Vedova et al., 1994). Also, between PN10 and PN22 there is a gradual increase in the fast-to-slow component amplitude ratio corresponding to expression of kinetically rapid non-NRs compared with kinetically slow NRs concurrent with mossy-fiber innervation (D'Angelo et al., 1993), and maturing cells in slices become less responsive to applied NMDA (Garthwaite and Garthwaite, 1986; Garthwaite et al., 1987). In culture, NR1a mRNA predominated at every stage in $25 \mathrm{~mm} \mathrm{KCl}$ or NMDA, whereas gradual induction of NR1b mRNA was observed in $5 \mathrm{~mm} \mathrm{KCl}$ (Fig. $6 B$ ), similar to ratios of NR1b/NR1a observed in situ. RT-PCR analyses of NR2 mRNA in whole cerebellum at PN7 (Fig. 2B) and granule cells at 0 DIV (Fig. $3 A$, prepared from PN8 cerebellum) confirmed that NR2B was the predominant transcript, with lower, but detectable, levels of NR2C and NR2A, possibly caused by maturing postmigratory cells. In culture, $25 \mathrm{~mm} \mathrm{KCl}$ or NMDA rapidly induced NR2A and downregulated NR2B, followed by gradual induction of NR2C after 7-12 DIV. Accordingly, single-channel analysis of granule cells in cerebellar slices supports the presence of NRs containing NR2A before PN14 and an additional type containing NR2C after PN14 (Farrant et al., 1994; Ebralidze et al., 1995). Using Northern hybridization analysis, Bessho et al. (1994) also observed a rapid induction of NR2A mRNA (twofold increase within $24 \mathrm{hr}$ ) in response to NMDA or elevated $\mathrm{KCl}$, although no appreciable changes were observed in other NR2 mRNAs, possibly caused by the use of relatively young cultures (no detectable NR2C) and/or insufficient sensitivity of the assay (no change in NR2B). In the present study, an early increase in NR2A and a delayed increase in $\mathrm{NR} 2 \mathrm{C}$ expression were observed in cells grown in $5 \mathrm{mM} \mathrm{KCl}$, but disappearance of NR2B occurred over a longer time course. Pending single-cell RT-PCR, we suggest that mRNAs from $5 \mathrm{~mm}$ cultures at 4-5 DIV come from two populations of cells containing different levels of NR subunit mRNAs. Those destined to survive $(\sim 30 \%)$ express proportionately higher levels of NR2A and lower levels of NR2B, similar to cells grown in $25 \mathrm{~mm} \mathrm{KCl}$, whereas those destined to be eliminated because of lack of NR stimulation $(\sim 70 \%)$ express high levels of NR2B, similar to immature cells at $0 \mathrm{DIV}$; this would account, therefore, for the apparent delay in NR2B downregulation when RNA from the mixed population was harvested and analyzed. Consistent with this theory, after 9-12 DIV in $5 \mathrm{~mm} \mathrm{KCl}$, the relative proportions of all three NR2 mRNAs in surviving cells were not significantly different from cells cultured in $25 \mathrm{~mm} \mathrm{KCl}$ (Fig. 5B).

Collectively, these data suggest that receptor channels containing primarily NR1a/NR2B predominate in migrating and early postmigratory cells, are downregulated rapidly in the presence of $25 \mathrm{~mm} \mathrm{KCl}$ or NMDA (or mossy-fiber activity in vivo) and, therefore, have an active role in migration but not differentiation (Komuro and Rakic, 1993; Rossi and Slater, 1993; Farrant et al., 1994). Activation of and transduction mediated by these NRs in the absence of identifiable synapses may be facilitated by their higher affinities for glutamate and glycine, higher peak current, and longer offset decay time constant compared with NRs containing NR2A (McBain and Mayer, 1994). At 3-4 DIV (or postmigration in vivo), as cells acquire dependence on neuronal activity for survival, a switch to NRs containing primarily NR1a/ 
NR2A is observed in a majority of cells grown in NMDA or $25 \mathrm{~mm}$ $\mathrm{KCl}$ media and in a minority of cells grown in $5 \mathrm{~mm} \mathrm{KCl}$ media. Compared with NRs containing NR2B, attenuation of temporal and spatial summation of synaptic events would result. Increased expression of NR2C mRNA and addition of NRs containing NR1a or b/NR2C and, possibly, NR1/NR2A/NR2C (Chazot et al., 1994) proceeds in conjunction with morphological, biochemical, and electrophysiological maturation of granule cells. NR1/NR2C channels have several features that distinguish them from NR1/ NK2A channels, including higher affinities for glutamate and glycine, longer offset decay time constants, and a reduced sensitivity to voltage-dependent $\mathrm{Mg}^{2+}$ block. In vivo, these properties are predicted to enhance the response to glutamate such that less synchronous and weaker postsynaptic depolarizations would activate the receptor channel. A preliminary report examining the electrophysiological properties of granule cells in thin cerebellar slices revealed that the macroscopic NR-mediated synaptic current in NR2C-deficient cells was twice the amplitude of wild-type controls (Ebralidze et al., 1995), indicating that inclusion of NR2C in synaptic NRs reduces net current flow.

The observed increase of NR1b unly in cells cultured in $5 \mathrm{mM} \mathrm{KCl}$ suggests the following: (1) the higher levels of neuronal activation obtained with long-term NMDA/ $15 \mathrm{mM} \mathrm{KCl}$ or $25 \mathrm{~mm} \mathrm{KCl}$ inhibit induction of NR1b but not NR2C; and (2) NR1b synthesis and NR2C synthesis are regulated independently, despite the fact that both are induced at later stages of maturation in situ. NRs containing NR1b demonstrate a lower apparent affinity for glutamate and NMDA, increased sensitivity to protein kinase $\mathrm{C}$ activators, and reduced sensitivities to protons and polyamines compared with NRs containing NR1a (Durand et al., 1992; Traynelis et al., 1995). The sensitivity to protons may be especially relevant because at physiological $\mathrm{pH}, \sim 50 \%$ of NRs containing NR1a + NR2A, NR2B, or NR2D are responsive to glutamate, whereas NRs containing NR1b are fully active (Traynelis et al., 1995). NRs containing either NR1 variant plus NR2C are not sensitive to proton inhibition. Thus, NR sensitivity to inhibition by protons would be manifest early in granule-cell development (Traynelis and Cull-Candy, 1991) when NR1a/NR2B or NR1a/NR2A predominate and would diminish gradually because of increased expression of both NR1b and NR2C subunits.

Further comparison of glutamate responses in primary cultures and slices will provide important insights into mechanisms by which NR activation regulates expression of distinct heteromeric forms of NRs to meet the different physiological requirements of developing and mature granule cells.

\section{REFERENCES}

Audinat E, Lambolez B, Rossier J, Crepel F (1994) Activity-dependent regulation of $N$-methyl-D-aspartate receptor subunits expression in cercbcllar granule cells. Eur J Neurosci 6:1792-1800.

Balazs R, Hack N (1990) Trophic effects of excitatory amino acids in the developing nervous system. Adv Exp Med Biol 268:221-228.

Balazs R, Jorgensen OS, Hack N (1988a) N-methyl-D-aspartate promotes the survival of cerebellar granule cells in culture. Neuroscience $27: 437-451$.

Balazs R, Gallo V, Kingsbury A (1988b) Effect of depolarization on the maturation of cerebellar granule cells in culture. Dev Brain Res 40:269-276.

Balazs R, Resink A, Hack N, Van der Valk JBF, Kumar KN, Michaelis E (1992) NMDA treatment and $\mathrm{K}^{+}$-induced depolarization selectively promote the expression of an NMDA-preferring class of the ionotropic glutamate receptors in cerebellar granule neurones. Neurosci Lett 137:109-113.
Bessho Y, Nawa H, Nakanishi S (1994) Selective up-regulation of an NMDA receptor subunit mRNA in cultured cerebellar granule cells by $\mathrm{K}^{+}$-induced depolarization and NMDA treatment. Neuron 12:87-95.

Bliss TVP, Collingridge GL (1993) A synaptic model of memory: longterm potentiation in the hippocampus. Nature 361:31-38.

Burgoyne RD, Pcarce IA, Cambray-Deakin MA (1988) N-methyl-Daspartate raises cytosolic calcium concentration in rat cerebellar granule cells in culture. Neurosci Lett 91:47-52.

Chazot PL, Coleman SK, Cik M, Stephenson FA (1994) Molecular characterization of $N$-methyl-D-aspartate receptors expressed in mammalian cells yields evidence for the coexistence of three subunit types within a discrete receptor molecule. J Biol Chem 269:24403-24409.

Chomczynski P, Sacchi N (1987) Single-step method of RNA isolation by acid guanidinium thiocyanate-phenol chloroform extraction. Anal Biochem 162:156-159.

Condorelli DF, Dell'Albani P, Aronica E, Genazzani AA, Casabona G, Corsaro M, Balazs R, Nicoletti F (1993) Growth conditions differentially regulate the expression of $\alpha$-amino-3-hydroxy-5-methylisoxazole4-propionate (AMPA) receptor subunits in cultured neurons. J Neurochem 61:2133-2139.

Constantine-Paton M, Cline HT, Debski E (1990) Patterned activity, synaptic convergence, and the NMDA receptor in developing visual pathways. Annu Rev Neurosci 13:129-154.

Cox JA, Felder CC, Henneberry RC (1990) Differential expression of excitalory aminu acid receptor subtypes in cultured cerebellar neurons. Neuron 4:941-947.

D'Angelo E, Rossi P, Taglietti V (1993) Different proportions of $N$-methyl-D-aspartate and non- $N$-methyl-D-aspartate receptor currents at the mossy fibre-granule cell synapse of developing rat cerebellum. Neuroscience 53:121-130.

Della Vedova F, Bonecchi L, Bianchetti A, Fariello RG, Speciale C (1994) Age-related changes in the relative abundance of NMDAR 1 mRNA spliced variants in the rat brain. NeuroReport 5:581-584.

Didier M, Roux P, Piechaczyk M, Verrier B, Bockaert J, Pin J-P (1989) Cerebellar granule cell survival and maturation induced by $\mathrm{K}^{+}$and NMDA correlate with c-fos proto-oncogene expression. Neurosci Lett 107:55-62.

Durand GM, Gregor P, Zheng X, Bennett MVL, Uhl GR, Zukin RS (1992) Cloning of an apparent splice variant of the $N$-methyl-Daspartate receptor NMDAR1 with altered sensitivity to polyamines and activators of protein kinase C. Proc Natl Acad Sci USA 89:9359-9363.

Ebralidze AK, Rossi DJ, Tonegawa S, Slater NT (1995) The role of the NR2C subunit in NMDA receptor-gated channels in mouse cerebellar granule cells. Soc Neurosci Abstr 21:592.

Farrant M, Feldmeyer D, Takahashi T, Cull-Candy SG (1994) NMDAreceptor channel diversity in the developing cerebellum. Nature 368:335-339.

Forrest D, Yuzaki M, Soares HD, Ng L, Luk DC, Sheng M, Stewart CL, Morgan JI, Connor JA, Curran T (1994) Targeted disruption of NMDA receptor 1 gene abolishes NMDA response and results in neonatal death. Neuron 13:325-338.

Gallo V, Kingsbury A, Baldzs R, Jorgensen OS (1987) The role of depolarization in the survival and differentiation of cerebellar granule cells in culture. J Neurosci 7:2203-2213.

Garthwaite G, Garthwaite J (1986) In vitro neurotoxicity of excitatory acid analogues during cerebellar development. Neuroscience 17:755-767.

Garthwaite G, Yamini Jr B, Garthwaite J (1987) Selective loss of Purkinje and granule cell responsiveness to $N$-methyl-D-aspartate in rat cerebellum during development. Dev Brain Res 36:288-292.

Hack NJ, Sluiter AA, Balazs R (1995) AMPA receptors in cerebeilar granule cells during development in culture. Dev Brain Res 87:55-61.

Hatten ME, Heintz N (1995) Mechanisms of neural patterning and specification in the developing cerebellum. Annu Rev Neurosci 18:385-408.

Hollmann M, Heinemann S (1994) Cloned glutamate receptors. Annu Rev Neurosci 17:31-108.

Irving AJ, Schofield JG, Collingridge GL (1992) The effect of $\left[\mathrm{K}^{+}\right]$ during culture on the appearance of spontaneous $\left[\mathrm{Ca}^{2+}\right]$ oscillations in rat cerebellar granule cells. Soc Neurosci Abstr 18:16.

Ishii T, Moriyoshi K, Sugihara H, Sakurada K, Kadotani H, Yokoi M, Akazawa C, Shigemoto R, Mizuno N, Masu M, Nakanishi S (1993) Molecular characterization of the family of the $N$-methyl-D-aspartate receptor subunits. J Biol Chem 268:2836-2843.

Ito $M$ (1984) The cerebellum and neural control. New York: Raven. 
Kamboj SK, Swanson GT, Cull-Candy SG (1995) Spermine confers rectification on rat calcium permeable AMPA and kainate receptors. J Physiol (Lond) 486:297-303.

Komuro H, Rakic P (1993) Modulation of neuronal migration by NMDA receptors. Science 260:95-97.

Kutsuwada T, Kashiwabuchi N, Mori H, Sakimura K, Kushiya E, Araki K, Meguro H, Masaki H, Kumanishi T, Arakawa M, Mishina M (1992) Molecular diversity of the NMDA receptor channel. Nature 358:36-41.

Lambolez B, Audinat E, Bochet P, Crepel F, Rossier J (1992) AMPA receptor subunits expressed by single Purkinje cells. Neuron 9:247-260.

Lasher RS, Zagon IS (1972) The effect of potassium on the neuronal differentiation in culture of dissociated newborn rat cerebellum. Brain Res 41:482-488.

Laurie DJ, Seeburg PH (1994) Regional and developmental heterogeneity in splicing of the rat brain NMDA-receptor 1 mRNA. J Neurosci $14: 3180-3194$.

Leahy JC, Chen Q, Vallano ML (1994) Chronic mild acidosis reduccs functional expression of NMDA receptors and enhances long-term survival in primary cultures of cerebellar granule cells. Neuroscience 63:457-470.

Levi G, Aloisi F, Ciotti MT, Thangnipon W, Kingsbury A, Balazs R (1989) Preparation of $98 \%$ pure granule cell cultures. In: A dissection and tissue culture manual of the nervous system (Shahar A, deVellis $\mathbf{J}$, Vernadakis A, Haber B, eds), pp 211-214. New York: Liss.

Lysko PG, Cox JA, Vigano A, Henneberry RC (1989) Excitatory amino acid neurotoxicity at the $N$-methyl-D-aspartate receptor in cultured neurons: pharmacological characterization. Brain Res 499:258-266.

MacDermott AB, Mayer ML, Westbrook GL, Jahr CE (1986) NMDA receptor activation increases cytoplasmic calcium concentration in cultured spinal cord neurons. Nature 321:519-522.

Mayer ML, Westbrook GL, Guthrie PB (1984) Voltagc-dependent block by $\mathrm{Mg}^{2+}$ of NMDA responses in spinal cord neurones. Nature 309:261-263.

McBain CJ, Mayer ML (1994) N-methyl-D-aspartic acid receptor structure and function. Physiol Rev 74:723-760.

Monaghan DT, Bridges RJ, Cotman CW (1989) The excitatory amino acid receptors: their classes, pharmacology, and distinct properties in the function of the central nervous system. Annu Rev Pharmacol Toxicol 29:365-402.

Monyer H, Burnashev N, Laurie DJ, Sakmann B, Seeburg PH (1994) Developmental and regional expression in the rat brain and functional properties of four NMDA receptors. Neuron 12:529-540.

Monyer H, Sprengel R, Schoepfer R, Herb A, Higuchi M, Lomeli H, Burnashev N, Sakmann B, Seeburg PH (1992) Heteromeric NMDA receptors: molecular and functional distinction of subtypes. Scicnce 256:1217-1221.

Moran J, Patel AJ (1989) Stimulation of the $N$-methyl-D-aspartate receptor promotes the biochemical differentiation of cerebellar granule neurons and not astrocytes. Brain Res 486:15-25.
Moriyoshi K, Masu M, Ishii T, Shigemoto R, Mizuno N, Nakanishi S (1991) Molecular cloning and characterization of the rat NMDA receptor. Nature 354:31-37.

Nakanishi S (1992) Molecular diversity of glutamate receptors and implications for brain function. Science 258:597-603.

Nakanishi N, Axel R, Shneider NA (1992) Alternative splicing generates functionally distinct $N$-methyl-D-aspartate receptors. Proc Natl Acad Sci USA 89:8552-8556.

Noonan KE, Roninson IB (1988) mRNA phenotyping by enzymatic amplification of randomly primed cDNA. Nucleic Acids Res 16:10366.

Nowak L, Bregestovski P, Aschcr P, Hcrbcrt A, Prochiantz A (1984) Magnesium gates glutamate-activated channels in mouse central neurons. Nature 307:462-465.

Pearson H, Graham ME, Burgoyne RD (1992) N-methyl-D-aspartate responses in rat cerebellar granule cells are modified by chronic depolarisation in culture. Neurosci Lett 142:27-30.

Rabacchi S, Bailly Y, Delhaye-Bouchaud N, Mariani J (1992) Involvement of the $N$-methyl-D-aspartate receptor in synapse elimination during cercbellar devclopment. Science 256:1823 1825.

Rossi DJ, Slater T (1993) The developmental onset of NMDA receptor channel activity during neuronal migration. Neuropharmacology 32:123y-1248.

Scheetz AJ, Constantine-Paton M (1994) Modulation of NMDA receptor function: implications for vertebrate neural development. FASEB J 8:745-752

Sheng M, Cummings J, Roldan LA, Jan YN, Jan LY (1994) Changing subunit composition of heteromeric NMDA receptors during development of rat cortex. Nature 368:144-147.

Traynelis SF, Cull-Candy SG (1991) Pharmacological properties and $\mathbf{H}^{+}$ sensitivity of excitatory amino acid receptor channels in rat cerebellar granule neurons. J Physiol (Lond) 433:727-763.

Traynelis SF, Hartley M, Heinemann SF (1995) Control of proton sẹnsitivity of the NMDA receptor by RNA splicing and polyamines. Science 268:873-876.

Tremblay E, Roisin MP, Represa A, Charriaut-Marlangue C, Ben-Ari Y (1988) Transient increased density of NMDA binding sites in the developing rat hippocampus. Brain Res 461:393-396.

Van der Valk JBF, Resink A, Balazs R (1991) Membrane depolarization and the expression of glutamate receptors in cerebellar granule cells. Eur J Pharmacol 201:247-250.

Watanabe M, Inoue Y, Sakimura K, Mishina M (1992) Developmental changes in distribution of NMDA receptor channel subunit mRNAs. NeuroReport 3:1138-1140.

Watanabe M, Mishina M, Inoue Y (1994) Distinct spatiotemporal expressions of five NMDA receptor channel subunit mRNAs in the cerebellum. J Comp Neurol 343:513-519. 